\title{
An Instructional Project Design based on CDIO
}

\author{
Zhangchong, zhongbaocai, Yandebiao \\ Chengdu Neusoft University, China \\ *zhangchong@nsu.edu.cn
}

Keywords: project design; CDIO; library system

\begin{abstract}
The process of conceive, design, implement and operate on a library system was introduced according to the principles of CDIO. Teaching target, principles for choosing project, content design, teaching method, teaching characteristics and evaluation criteria are emphasized in the project. It was also successfully implemented in the practice, activated the study enthusiasm of students and speeded up the step of the CDIO reform in the institute.
\end{abstract}

\section{CDIO Introduction}

The engineering educational pattern CDIO is the latest achievement of international engineering education reform in recent years. The international studies of four universities, including MIT and the Royal Swedish Institute of Technology originated the CDIO Engineering education concept, and founded the international Cooperation Organization named by CDIO through many years. The idea of CDIO not only inherits and develops the concept of the engineering education reform in Europe and the United States, but more importantly, it systematically proposed 12 standards for ability training and evaluation.

CDIO represents the idea of Conceive, Design, Implement and Operate ${ }^{[1]}$.It takes the product lifecycle from development to the implementation as carrier, and it allows students to learn engineering in an active, practical way. CDIO syllabus divides the ability of engineering graduates into four levels which includes engineering basic knowledge, personal ability, interpersonal team ability and engineering system capability. The syllabus requires students to reach their goals at these four levels through a comprehensive training.

\section{Project design process}

Chengdu Neusoft University has introduced CDIO education idea for many years, the following is an example of how an instructional project is developed in the short term of this school under the idea.

\subsection{Determine the teaching objectives.}

First, we set the teaching objectives according to the syllabus of the project:

Table 1 Teaching Objectives

\begin{tabular}{|c|l|}
\hline $\begin{array}{c}\text { Target } \\
\text { content }\end{array}$ & \multicolumn{1}{c|}{ Specific objectives } \\
\hline \multirow{4}{*}{$\begin{array}{c}\text { Theoretical } \\
\text { knowledge }\end{array}$} & 1. Master the basic syntax of Java \\
\cline { 2 - 3 } & 2. Understand the basics of Swing \\
\cline { 2 - 2 } & 3. Understand the basics of IO and JDBC \\
\hline \multirow{2}{*}{$\begin{array}{c}\text { Professional } \\
\text { skills }\end{array}$} & 1. Apply the programmatic capabilities by using common Swing controls \\
\cline { 2 - 3 } & 2. Apply the programmatic capabilities by using file IO \\
\hline
\end{tabular}


3. Apply the programmatic capabilities to access a database by using JDBC

1. Has a good working attitude and a sense of responsibility

Ethics

2. Has strong team awareness and collaboration capabilities

3. Has better language capabilities

\subsection{Make sure the capacity index needed to train.}

According to the CDIO syllabus and the training objectives of the software engineering major, we make sure the capacity index system for the short term project as follows:

Table 2 CDIO capability index

\begin{tabular}{|c|c|c|c|}
\hline $\begin{array}{c}\text { CDIO } \\
\text { capability } \\
\text { index(level 1) }\end{array}$ & $\begin{array}{l}\text { CDIO capability } \\
\text { index(level 2) }\end{array}$ & $\begin{array}{l}\text { CDIO capability } \\
\text { index(level 3) }\end{array}$ & Project Training Capacity Index \\
\hline \multirow{2}{*}{$\begin{array}{l}1 \text { Technical } \\
\text { knowledge and } \\
\text { reasoning } \\
\text { capabilities }\end{array}$} & \multirow{2}{*}{$\begin{array}{l}\text { 1.3 Advanced basic } \\
\text { knowledges }\end{array}$} & $\begin{array}{l}\text { 1.3.1 Software } \\
\text { Engineering } \\
\text { Development } \\
\text { Knowledge }\end{array}$ & $\begin{array}{l}\text { Master the popular software development process model, and } \\
\text { the basic principles of software Engineering project } \\
\text { development. }\end{array}$ \\
\hline & & $\begin{array}{l}\text { 1.3.3 Engineering } \\
\text { Project } \\
\text { Knowledge }\end{array}$ & $\begin{array}{l}\text { Master how to write software development related } \\
\text { documents, understand the software development process, } \\
\text { cultivate students ' teamwork awareness with software } \\
\text { Development Engineer professional quality. }\end{array}$ \\
\hline \multirow{3}{*}{$\begin{array}{l}2 \text { Open minded } \\
\text { and innovation }\end{array}$} & \multirow{2}{*}{$\begin{array}{l}2.1 \text { System } \\
\text { Thinking }\end{array}$} & $\begin{array}{l}\text { 2.1.1 Holistic } \\
\text { Thinking }\end{array}$ & $\begin{array}{l}\text { Identify and define a software project system, system } \\
\text { behavior, and system units; Identify the interaction between } \\
\text { the system and the outside world and the impact on system } \\
\text { behavior }\end{array}$ \\
\hline & & $\begin{array}{l}2.1 .2 \text { presentation } \\
\text { and interaction of } \\
\text { systems }\end{array}$ & $\begin{array}{l}\text { Know how to define a system and system modeling, the } \\
\text { behavior and function characteristics of the system, and the } \\
\text { identification of important interfaces between system units. }\end{array}$ \\
\hline & $\begin{array}{l}2.3 \text { Creative } \\
\text { Thinking }\end{array}$ & $\begin{array}{l}2.3 .1 \text { ability to } \\
\text { conceptualize and } \\
\text { abstract }\end{array}$ & $\begin{array}{l}\text { For specific applications and practical problems, we can use } \\
\text { the knowledge to abstract the problem, extract its logical } \\
\text { structure and storage structure. }\end{array}$ \\
\hline \multirow{4}{*}{$\begin{array}{l}3 \text { Personal and } \\
\text { professional skills } \\
\text { ability }\end{array}$} & \multirow{3}{*}{$\begin{array}{l}3.1 \text { ability to reason } \\
\text { and solve problems }\end{array}$} & $\begin{array}{l}3.1 .1 \text { discovering } \\
\text { and expressing } \\
\text { problems }\end{array}$ & $\begin{array}{l}\text { In specific projects, can find engineering requirements and } \\
\text { design issues involved, and can describe them clearly. }\end{array}$ \\
\hline & & 3.1.2 Modeling & $\begin{array}{l}\text { In a specific project, can carry on the preliminary modelling, } \\
\text { and design reasonable system structure }\end{array}$ \\
\hline & & $\begin{array}{l}\text { 3.1.5 Resolve } \\
\text { questions } \\
\text { and } \\
\text { Recommendations }\end{array}$ & $\begin{array}{l}\text { In a specific engineering application, can find the problem, } \\
\text { solve the problem, and put forward the reasonable } \\
\text { suggestion. }\end{array}$ \\
\hline & $\begin{array}{l}3.3 \text { Information } \\
\text { Processing } \\
\text { Capabilities }\end{array}$ & $\begin{array}{l}\text { 3.3.2 Information } \\
\text { Reprocessing } \\
\text { Capabilities }\end{array}$ & $\begin{array}{l}\text { Having the ability to process information in the relevant areas } \\
\text { and to properly handle the information, resulting in effective } \\
\text { information or knowledge to guide decision-making. }\end{array}$ \\
\hline $\begin{array}{l}4 \text { Communication } \\
\text { and teamwork, }\end{array}$ & $\begin{array}{l}\text { 4.1 Communication } \\
\text { Capabilities }\end{array}$ & $\begin{array}{l}4.1 .3 \text { written } \\
\text { communication }\end{array}$ & $\begin{array}{l}\text { To format the document and to demonstrate the writing } \\
\text { ability of the related aspects of software development } \\
\text { technology. }\end{array}$ \\
\hline 7 Ethical Values & $\begin{array}{l}\text { 7.2 Professional } \\
\text { Values }\end{array}$ & $\begin{array}{l}7.2 .3 \text { individuals } \\
\text { and teams grow } \\
\text { together }\end{array}$ & $\begin{array}{l}\text { Recognize the affiliation of individual and team, establish the } \\
\text { consciousness of promoting the growth of the team with } \\
\text { self-development. }\end{array}$ \\
\hline
\end{tabular}




\begin{tabular}{|c|c|c|c|}
\hline \multirow{5}{*}{$\begin{array}{l}8 \text { Social } \\
\text { Contribution by } \\
\text { practice ( CDIO ) }\end{array}$} & \multirow{2}{*}{$\begin{array}{l}8.4 \text { conceptual and } \\
\text { engineering of } \\
\text { systems }\end{array}$} & $\begin{array}{l}8.4 .2 \text { define } \\
\text { features, concepts, } \\
\text { and structures }\end{array}$ & $\begin{array}{l}\text { To enable students to master and apply software development } \\
\text { engineering ideas, thinking of engineering methods to solve } \\
\text { problems. }\end{array}$ \\
\hline & & $\begin{array}{l}8.4 .3 \text { system } \\
\text { modeling and } \\
\text { ensuring goal } \\
\text { implementation }\end{array}$ & Ability to do preliminary modeling. \\
\hline & 8.5 Design & $\begin{array}{l}\text { 8.5.2 segmentation } \\
\text { and methods of the } \\
\text { design process }\end{array}$ & $\begin{array}{l}\text { Master all stages of project design and various design } \\
\text { analysis methods. }\end{array}$ \\
\hline & \multirow{2}{*}{ 8.6 Implementation } & $\begin{array}{l}\text { 8.6.1 Design } \\
\text { Implementation } \\
\text { Process }\end{array}$ & $\begin{array}{l}\text { Define the process and resource requirements of project } \\
\text { implementation, and have the design capability of project } \\
\text { implementation. }\end{array}$ \\
\hline & & $\begin{array}{l}\text { 8.6.3 Software } \\
\text { Implementation } \\
\text { Process }\end{array}$ & $\begin{array}{l}\text { Understand the design of each module in the system, } \\
\text { implement the underlying design (programming) using the } \\
\text { programming language }\end{array}$ \\
\hline
\end{tabular}

\subsection{Choose a suitable project.}

The purpose of choosing an appropriate project is to enable students to solve practical engineering problems from the study of professional knowledge, stimulate students ' interest in practical engineering problems, and guide them to explore and master the ways and means to solve problems ${ }^{[3]}$. First, the project can't be too big or too small. Second, The project should be as close to the real project as possible, but the difference is to remove parts of the real project those are too difficult or impossible for students to implement. For the topic of the project,it should be as familiar as possible to the students, and the business process is also easy to understand. To combine all of the above principles, we choose a very common library management system, because the students have oppotunities to use it when they borrow or return books.

\subsection{Teaching content design}

The function design of library management system often determines the knowledge and skill that students should master. Before the short term, students have finished learning some Java programming and database knowledges, and to complete the system also requires the knowledge of the above courses. For example, to implement the display function of the book type classification, we need the data structure of the tree-related knowledge; In the realization of the book to add, delete,modify and search function, we need to create a database, and access to the database. The entire system is implemented in Java programming language, and of course requires the object-oriented, circular control, file IO operations and other knowledge.During the process of the development of the library system,the students also learned the subject knowledge, which is actually an integrated learning experience, namely CDIO standard 7 , that is, "integrated learning experience leads to the acquisition of discipline knowledge with personal and interpersonal skills, product, process, and system building capabilities"[2].

\subsection{Teaching method}

Group teaching method not only brings the spirit of teamwork, but also shows the process of real software project development.In the modern software development process, very few software is developed by individuals, while most of them come from a team or a group. By working in groups, you can enable students to experience the real environment in the future. In the first class, we distributed questionnaires to the whole class, mainly to get to know their basic knowledge and the way to group. Finally, we found that most of the students would like to join a team for freedom. In view of this, we set some rules for making groups. For example, boys and girls should be in an average proportion, with top and bottom students keeping a good balance. 


\subsection{Project Development Schedule}

Then we set out the teaching tasks and schedule, which requires students to complete a library management system in three phases in groups. The first week is the first stage, which is mainly the review of previous knowledge and the supplement of new knowledge needed for project development. The second to third week is the second stage, the students join a group for free to develop the project.The students will develop the project by themselves, while they can ask the teacher any questions if they meet some problems. The last week is the third stage,the students should submit the reports and the sourcecode of the project,they also need to make a project demonstration and representation.

\subsection{Teaching characteristics}

What is taught in textbooks is often different from what is required in real work, especially for the commercial software. Therefore, we need to introduce real-world development skills in practical projects. For example, in the Library Management System, there is a user login module, the common process is to compare the user name and password input by the user with the same information stored in the database. The user will be allowed to enter into the system if they can match,or vice versa. But in the real project, the password is not stored in the database in plaintext, it generally has to be encrypted (such as the use of the MD5 encryption algorithm)before storage.So, we need to consider about it. For another example, the Statement class that accesses the database is a very common object, but in real-world development, we often use a more efficient precompiled statement class Preparedstatement, and therefore a similar requirement for students. Because the real environment of software development put forward higher requirements for the students, they need to consider more carefully and thoughtful, which prompt the students to study actively and take the initiative to think and solve problems, which also introduces the CDIO standard 1: "Development and application of product, process, and system lifecycle - conceive, design, implement, run as background environment for engineering education" ${ }^{[2]}$ and Standard 8:" Teaching and learning based on active experience learning method " [2].

The complete development process is another feature. The small term practice is a comprehensive project training, so the process of software development should be complete, including requirements analysis, overview design, detailed design, coding, testing and maintenance. Students will have to go through all the stages to complete a project, and thus have a complete and comprehensive understanding of the project's entire development process. The student's requirements are also different in different phrases.For example, keen observation and analytical ability is needed in the requirement analysis phrase, a certain sense of abstraction is needed in the overview design and detailed design phrase, a solid professional knowledge and skills is required in the coding phrase, while careful logical thinking ability and strong sense of responsibility is required in the testing and maintenance phrase, which also reflects the vast majority of the CDIO capability index system.

\subsection{Evaluation Method}

The evaluation of students ' knowledge and ability is an important part of teaching. The traditional way of passing exam papers has a lot of drawbacks, since a student can get high grade in an exam with no any programming experience. So we use a variety of methods in the small term evaluation method. That is, the student's total score is composed of the usual scores and the project results. The usual performance accounts for $40 \%$, while the project results account for $60 \%$. The usual performance comes from the daily attendance and weekly report submitted to the teacher, each accounted for half. Student attendance can reflect a student's learning attitude, the weekly report can reflect whether the students are seriously developing the project. The project results are composed of the project report, the project oral defense and the group grading. The project report accounts for $40 \%$ of the project results, which is the final paper to be submitted to the teacher, and is also the summary of this month the student has learned.The group score was graded by the team leader who was the best known to the 
group, so that his or her rating reflects the true status of the contributions made by members to the group project, thus reflecting the differences among the members. The evaluation method combines process assessment with achievement assessment, and combines teacher evaluation with student evaluation, which can reflect students ' mastery of knowledge and ability, and fully introduces the standard of CDIO 11 : "Evaluate students ' learning effects in terms of personal, interpersonal skills, product, process and system building capabilities, and discipline knowledge" [2].

\section{Conclusions}

The instructional project is finished smoothly according to our plan. Some students did a very good job, and they also feel learned a lot.

In summary, CDIO 12 standards is embodied in any stage of the small term project training, and the training fact proves that the teaching reform of CDIO in Chengdu Neusoft College has achieved a great success which will make an important contribution to the improvement of the quality of this university.

\section{References}

[1]. Chajianzhong. On the "Do Middle school" strategy under the CDIO mode [J]. Research on higher engineering Education, 2008 (3): 1-9..

[2]. Edward F.crawley, Johan malmqvist, Soren Ostlund, et al. re: Understanding Engineering Education: International CDIO Culture mode and Method [M]. Gu Peihua, Shen, Xiaohua, translate. . BEIJING: higher Education Press , 2009,97,254

[3]. Shite. Design and practice of level three projects based on the CDIO concept [J]. Education and Occupation: 154.

[4]. Wen Tao. Exploration and practice of integrated talent training model based on TOPCARES-CDIO [J]. Computer Education,8 (1): 23-29. 